\title{
Mutual influence of herpes virus infection activation and cerebral circulation impairment on the state of brain cells
}

\author{
A. V. Gumenyuk ${ }^{1}$, N. V. Motorna ${ }^{1}$, S. L. Rybalko ${ }^{2}$, S. I. Savosko ${ }^{1}$, \\ L. M. Sokurenko ${ }^{1}$, Yu. B. Chaikovsky ${ }^{1}$ \\ ${ }^{1}$ Bogomolets National Medical University \\ Blvd. Shevchenko, 13, Kyiv, Ukraine, 01601 \\ ${ }^{2}$ Gromashevsky L. V. Institute of Epidemiology and Infection Diseases, NAMS of Ukraine \\ 5, Amosova Str., Kyiv, Ukraine, 03038 \\ savosko_s@ukr.net
}

\begin{abstract}
Aim. To define the development of herpes virus infection and morphological changes in the brain a upon a cerebrovascular accident. Methods. The experiments were performed on white mice weighing 18-20g. The animals were infected with type I HSV. Stroke was simulated after recovery and the rate of virus reactivation was determined. The rate of HSV production was evaluated by determination of viral antigens in Vero cell culture, PCR and dot-ELISA methods. The neurodegenerative process was confirmed by histological examination. Results. Reactivation of HSV-I was detected after the stroke. Histological study confirmed anincreased degree of neurodystrophic process around the hemorrhage, including hippocampus. A diagnostic value of the molecular methods has been proven in the detection of herpes infection in the biological samples (plasma, homogenates of animal organs). Conclusions. This study provided new data on the pathogenesis of herpes virus infection after acute stroke and its place in the development of complications. We have shown that the ischemic brain damage was a factor of type I HSV reactivation and it was characterized by a higher rate of neurodegenerative changes in hippocampus as compared to the isolated development of neuroinfection or impairment of cerebral circulation.
\end{abstract}

Ke y w or d s: herpes, stroke, diagnostics, pathogenesis.

\section{Introduction}

Recently there has been an essential expansion of the spectrum of diseases associated with herpes viruses. Herpes viruses belong to the most widespread viruses causing various diseases in humans [1-4]. Herpes simplex virus (HSV type I and II) persists in the immunosuppressed patients and may cause meningitis, and vasculitis [5-7]. Relationship between the development of ischemic and hemorrhagic stroke in the presence of HSV was described in a number of studies [1, 8, 9]. Reproduction of virions occurs within quite a short period of time as indicated by the appearance of $\operatorname{IgG} 16$ days after the stroke. At the same time it was shown that antiviral treatment, acyclovir in particular, does not prevent post-stroke HSV reactivation [9].

An early diagnosis of the viral infection activation is no less critical, including the assessment of the herpes infection contribution to the development of stroke depending on the specific features of detecting virus in plasma and CSF of patients and experimental animals. HSV is detected by PCR, ELISA, and by specific IgM and IgG titer. As shown by PCR testing the rate of virus detection in plasma is $29 \%$, and $59 \%$ in CSF [6]. These data make [relevant] the study of

(C) 2016 A. V. Gumenyuk et al.; Published by the Institute of Molecular Biology and Genetics, NAS of Ukraine on behalf of Biopolymers and Cell. This is an Open Access article distributed under the terms of the Creative Commons Attribution License (http://creativecommons.org/licenses/by/4.0/), which permits unrestricted reuse, distribution, and reproduction in any medium, provided the original work is properly cited 
the potential post-stroke reactivation of HSV and its role in the progression of neurodegenerative changes.

The study was aimed at investigating the mutual effect of impaired cerebral circulation and activation of herpes virus infection induced by it on the state of brain cells.

\section{Materials and Methods}

Experiments were conducted on white mice weighing 18-20 g. The animals were subdivided into 4 groups (Table 1).

Table 1. Groups of experimental animals

\begin{tabular}{|l|c|}
\hline \multicolumn{1}{|c|}{ Group } & Number of animals \\
\hline Control & 10 \\
HSV-I & 110 \\
Stroke & 15 \\
HSV-I+stroke & 37 \\
\hline
\end{tabular}

HSV-I reactivation was studied on [the] herpetic meningoencephalitis model. Being suitable for assessing severity of symptoms, this model is $100 \%$ reproducible and does not require any additional methods of control. The freeze-dried HSV type I VC strain was used. $0.03 \mathrm{ml}$ of viral material, which equals to LD50, was inoculated into the brains of mice. Initial symptoms of the infectious condition in the control were observed 5-6 days after the infection and reached their maximum by day 13-14 with the following subsidence of symptoms and recovery of animals. We assume that this is the time when HSV-I transfers into its latent form.

On day 30-40 after the regression of the viral infection signs (weakness, hypokinesia, decreased food and water requirements) a hemorrhagic stroke was simulated in the survivors. Cerebral hemorrhage in animals was simulated by inoculation of $0.15-0.2 \mathrm{ml}$ of autologous blood into the right hemisphere $(\mathrm{L}=1.5$; $\mathrm{H}=3.0 ; \mathrm{AP}=1.0$ ) - надо расшифровать? [10].

PCR and dot-ELISA were used to confirm [the] HSV-I reproduction by detecting viral antigens in Vero cell culture. Vero cell culture was grown in sterile trays ("Nunc"). The infected trays were incubated in culture medium (88\% RPMI 1640 medium
"Sigma") with addition of $12 \%$ of heat inactivated fetal calf serum (FCS) and antibiotics at $37{ }^{\circ} \mathrm{C}$ with $5 \%$ of $\mathrm{CO}_{2}$. Cytopathic activity (CPA) - syncytia formation - served as a marker of viral reproduction. CPA has been registered for 6-7 days.

HSV-I DNA in biological specimens was found by PCR with hybridization-fluorescent detection using the set of reagents "AmplySens ${ }^{\mathrm{R}}$ HSV- I, II-FL". "DNA-sorb-AM" set of reagents was used for DNA extraction. DNA was extracted from each studied specimen in the presence of internal control specimen (BKO-FL).

Dot- ELISA was performed on nitrocellulose filters. The filters with the applied specimens were dried and immersed in the solution containing $30 \mathrm{mg} / \mathrm{ml}$ BSA in $0.01 \mathrm{M}$ Tris $\mathrm{pH} 7.5-0.15 \mathrm{M} \mathrm{NaCl}$ buffer, and incubated for two hours at $37{ }^{\circ} \mathrm{C}$. After the incubation in PAP (peroxidase-antiperoxidase complex) the filters were rinsed six times and immersed into the substrate for an enzyme to develop: $3.8 \mathrm{ml}$ of DAB (diaminobenzidine tetrachloride) + $0.2 \mathrm{ml}$ of $0.1 \% \mathrm{H}_{2} \mathrm{O}_{2}$. The reaction was registered when the centers of the wells turned yellow.

For histological examination the murine brain was fixed in $10 \%$ formalin solution in $0.1 \mathrm{M}$ phosphate buffer ( $\mathrm{pH} 7.4$ ), dehydrated in increasing concentrations of ethanol and embedded in paraffin as per the standard procedure. The paraffin slices $6-8 \mu \mathrm{m}$ thick were stained with hematoxilin and eosin.

The morphometric study included assessment of the changes in the number of damaged neurons in the frontal hippocampal sections. The microphotographs were taken with Olympus BX 51 microscope. The morphometric analysis was performed using CarlZeiss (AxioVision SE64 Rel.4.9.1) software, magnification $x 400$. Statistica 6.0 software was employed for statistical processing of the obtained data using Student t-test.

\section{Results and Discussion}

[The] Presence of HSV in the experimental specimens was confirmed by the methods of molecular biology. Dot-ELISA detected HSV type I in $100 \%$ [of] specimens of blood serum and brain homoge- 

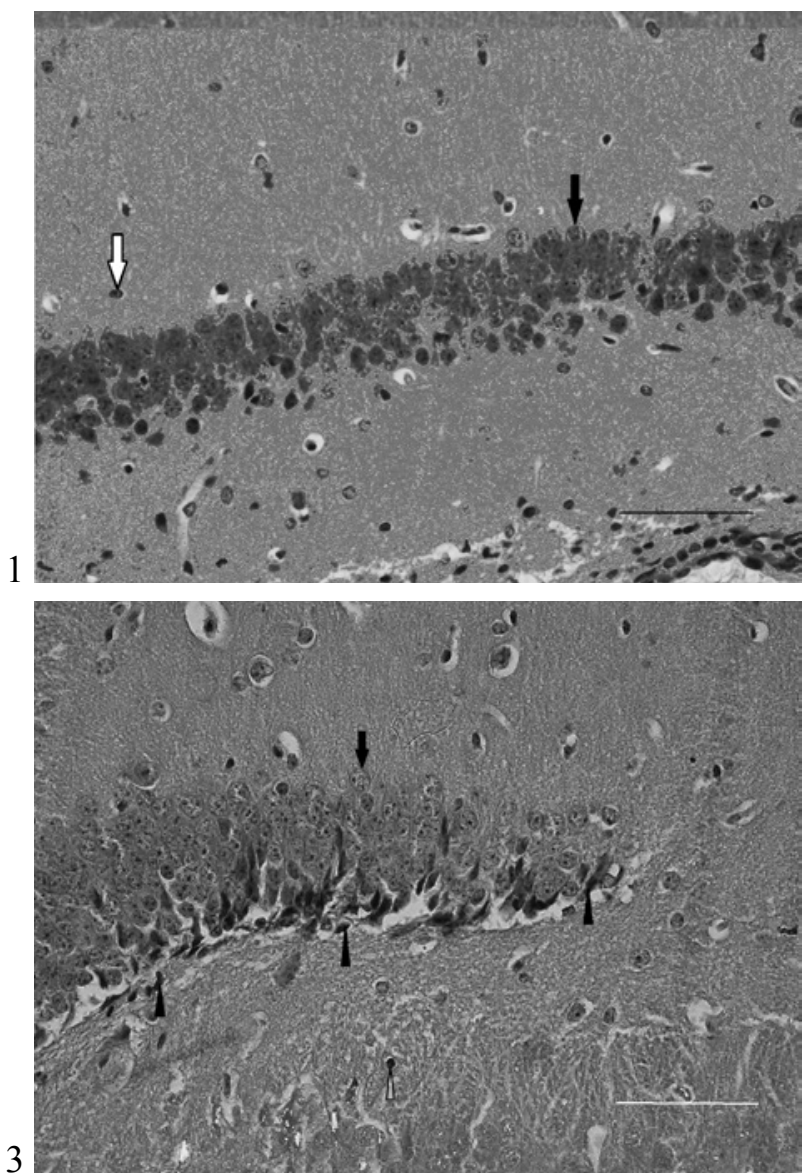
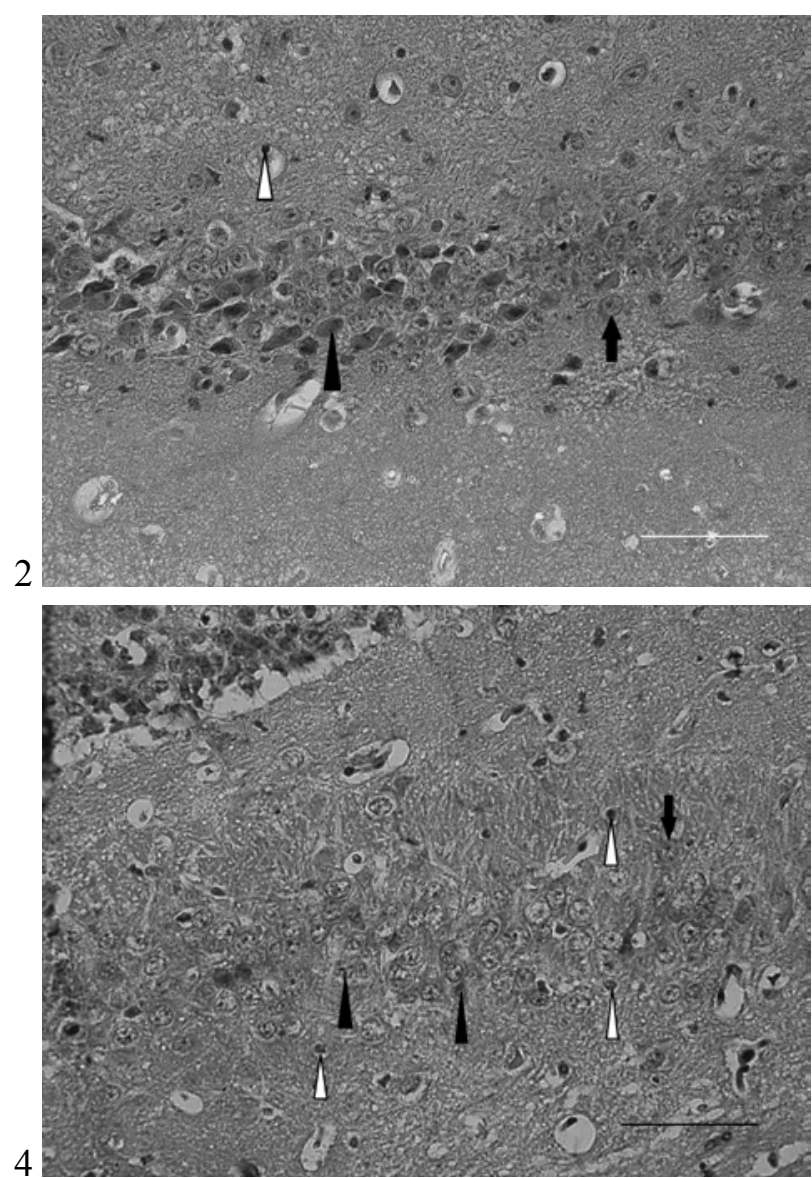

Fig. 1. Hippocampus of mice from the control and study groups. The increased degree of neurodegenerative changes in hippocampal neurons of animals with herpes virus infection after simulated stroke. Legend: 1 - control; 2 - stroke; 3 - HSV-I; 4 - HSVI+hemorrhagic stroke; $\prec$ - intact glial cell; - intact neuron; $\square$ - apoptotic glial cell; $\longrightarrow$ - apoptotic/necrotic neuron. H\&E. Scale $-100 \mu \mathrm{m}$.

nates. PCR also confirmed HSV-I DNA reproduction in the groups of experimental animals in the acute (day 5) and long term (day 30) periods of herpetic infection. HSV-I was also found in $100 \%$ [of] specimens obtained from animals with latent infection which developed after the simulated stroke.

CPA assessment on Vero culture allowed quantification of the rate of HSV-I reproduction in biological specimens. The changed infection titer in the experimental animals within 5-30 days after infection was found in:

animals HSV-I carriers - CPA decreased from 2.0 up to $1.2 \mathrm{LD}_{50}$ and in the brain from $3.2 \mathrm{up}$ to $2.0 \mathrm{LD}_{50}$; animals HSV-I carriers after the stroke - increased CPA in serum and brain from 1.4 up to $3.0 \mathrm{LD}_{50}$.

Histological methods have confirmed the increased volume of the neurodystrophy focus in brain structures during the stroke simulation in animals HSV-I carriers. The morphological signs of herpes virus infection included emergence of multinucleolated hypertrophied neuronal nuclei and atypical perinuclear space, and apoptotic hyperchromatic neurons (Fig. 1). The local hemorrhage, focal sites with signs of necrosis and swelling of the nerve tissue in the internal capsule, in the corpus callosum, hippocampus and sensory motor cortex were found 
Mutual influence of herpes virus infection activation and cerebral circulation impairment on the state of brain cells

Table 2. Results of molecular-biological and histological studies

\begin{tabular}{|l|c|c|c|c|c|}
\hline \multicolumn{1}{|c|}{ Group } & PCR & dot-ELISA & $\begin{array}{c}\text { CAP of the infectious } \\
\text { titer, } \text { ID }_{50}\end{array}$ & $\begin{array}{c}\text { Area of neuronal } \\
\text { nuclei, } \mu \mathrm{m}^{2}\end{array}$ & $\begin{array}{c}\text { Percentage of apoptotic/necrotic } \\
\text { neurons, } \%\end{array}$ \\
\hline Control & - & - & - & $87.6 \pm 2.0$ & $3.4 \pm 0.1$ \\
HSV ВПГ-I & + & + & $2.0 \pm 0.0$ & $54.4 \pm 1.7$ & $59.5 \pm 5.6$ \\
Stroke & - & - & - & $103.4 \pm 2.4$ & $78.7 \pm 9.1$ \\
HSV-I+stroke & + & + & $3.0 \pm 0.3$ & $63.9 \pm 2.7$ & $88.3 \pm 5.3$
\end{tabular}

in animals with right hemisphere stroke. Swelling was associated with the change of morphometric neuronal indicators - the nucleus area increased by $18.3 \%(\mathrm{p}<0.05)$ (Table 2). Stroke simulation in the animals-HSV-I carriers resulted in a dramatic increase in the number of neurons with signs of apoptosis and necrosis, and the increase of neurodegenerative changes rate up to $28.8 \%(p<0.05)$.

Thus, the results of the complex virological and histological study provided new data on the herpes virus infection pathogenesis associated with the stroke. The specific features of the infectious process development presented in the study on quite a big number of laboratory animals have confirmed the hypothesis about the reactivation of latent HSV-I in CNS after the local stroke. The development of immune deficient states, which might be caused by traumatic and ischemic damages of the nervous system is considered to be the cause of HSV-I reactivation $[1,9]$. The increased rate of structural hippocampal changes observed in the study after the simulated hemorrhagic stroke in the animals HSV-I carriers may be explained by the dysfunction of the local immune competent cells, since micro glial cells are known to produce chemokine and cytokines, initiating the cascade of neuro-immune responses [11]. However, no signs of leucocyte infiltration and gliosis were registered in the hippocampal regions, conversely, a significant number of apoptotic glial cells was observed, which is also a sign of progressive neurodegenerative change in the presence of concurrent impairment of cerebral circulation and hence the factor of exacerbation of the pathological condition. The data obtained are important for understanding the pathogenesis of herpes virus infection.

\section{Conclusions}

The experimental study has provided new data regarding the pathogenesis of herpes virus infection after the acute stroke and its place in the development of complications. It has been shown that the ischemic brain damage is a factor of the type I HSV reactivation and is characterized by a higher rate of neurodegenerative changes in hippocampus as compared to the neuroinfection or the impairment of cerebral circulation developed independently.

\section{REFERENCES}

1. Alexandri NM, Tavernarakis A, Potagas $C$, Molari H, Koutra $H$. [Ischemic stroke and herpes simplex virus type-1 associated meningoencephalitis]. Rev Neurol (Paris). 2004; 160(5 Pt 1):579-81.

2. Guerrero WR, Dababneh H, Hedna S, Johnson JA, Peters $K$, Waters $M F$. Vessel wall enhancement in herpes simplex virus central nervous system vasculitis. J Clin Neurosci. 2013;20(9):1318-9.

3. Nagel MA, Gilden D. The relationship between herpes zoster and stroke. Curr Neurol Neurosci Rep. 2015;15(4):16.

4. Nagel MA, Choe A, Khmeleva N, Overton L, Rempel A, Wyborny A, Traktinskiy I, Gilden D. Search for varicella zoster virus and herpes simplex virus-1 in normal human cerebral arteries. J Neurovirol. 2013;19(2):181-5.

5. Ballaekere JS, Chebbi PP, Sundarmurthy H, Parameshwarappa $A$. Weber syndrome: herpes simplex virus brainstem encephalitis as an etiology. Am J Med. 2014;127(12):e5-6.

6. To TM, Soldatos A, Sheriff $H$, Schmid DS, Espinosa $N$, Cosentino $G$, Preas $C P$, Glaser $C A$. Insights into pediatric herpes simplex encephalitis from a cohort of 21 children from the California Encephalitis Project, 1998-2011.

7. Snider SB, Jacobs CS, Scripko PS, Klein JP, Lyons JL. Hemorrhagic and ischemic stroke secondary to herpes simplex virus type 2 meningitis and vasculopathy. J Neurovirol. 2014;20(4):419-22.

8. Sas AM, Niks EH, Lequin MH, Catsman-Berrevoets CE, de Wit $M C$. Herpes simplex virus type-1 encephalitis and occipital ischemic stroke. Pediatr Neurol. 2009;41(4):294-6. 
9. Terlizzi V, Improta F, Di Fraia T, Sanguigno E, D'Amico A, Buono $S$, Raia $V$, Boccia $G$. Primary herpes virus infection and ischemic stroke in childhood: a new association? J Clin Neurosci. 2014;21(9):1656-8.

10. Franklin $K$, Paxinos $G$. The mouse brain in stereotaxic coordinates. Gulf Professional Publishing. 2004, 100 p.

11. Lokensgard JR, Cheeran MC, Hu S, Gekker G, Peterson $P K$. Glial cell responses to herpesvirus infections: role in defense and immunopathogenesis. J Infect Dis. 2002;186 Suppl 2:S171-9.

\section{Взаємний вплив активації герпесвірусної інфекції, опосередкованої порушенням мозкового кровообігу, на стан клітин головного мозку}

А. В. Гуменюк, Н. В. Моторна, С. Л. Рибалко, С. І. Савосько, Л. М. Сокуренко, Ю.Б. Чайковський.

Мета. Дослідити взаємний вплив порушення мозкового кровообігу та опосередкованої ним активації герпесвірусної інфекції на стан клітин головного мозку. Методи. Проведено експериментальне дослідження на білих мишах вагою 18-20 г. Тварин заражали ВПГ І типу, після виліковування моделювали інсульт і визначали рівень реактивації вірусу. Рівень продукції ВПГ оцінювали методом визначення вірусних антигенів у культурі клітин Vero, методом ПЛР i dot-ELISA. Нейродегенеративний процес вивчали гістологічним дослідженням. Результати. Після експериментального інсульту встановлено реактивацію ВПГ І типу. Гістологічним дослідженням підтверджено наявність нейродистрофічного процесу навколо вогнища крововиливу, зокрема - у гіпокампі. Робота продемонструвала діагностичну цінність молекулярно-біологічних методів у виявленні герпесвірусної інфекції у біологічних зразках (плазмі крові, гомогенатах органів тварин). Висновки. Експериментальне дослідження дало нові дані щодо патогенезу герпесвірусної інфекції після гострого інсульту та їі місця у розвитку усклад- нень. Додатково показано діагностичну цінність лабораторних методів визначення ВПГ.

К л юч о в і с л о в а: герпес, інсульт, діагностика, патогенез.

Взаимное влияние активации герпесвирусной инфекции, опосредованной нарушением мозгового кровообращения, на состояние клеток головного мозга

А. В. Гуменюк, Н. В. Моторная, С. Л. Рыбалко, С. И. Савосько, Л. М. Сокуренко, Ю. Б. Чайковский.

Цель. изучить взаимное влияние нарушения мозгового кровообращения и опосредованной им активации герпесвирусной инфекции на состояние клеток головного мозга. Методы. Проведено экспериментальное исследование на белых мышах весом 18-20 г. Животных заражали ВПГ І типа, после излечения моделировали инсульт и определяли уровень реактивации вируса. Уровень продукции ВПГ оценивали методом определения вирусных антигенов в культуре клеток Vero, методом ПЦР и dotELISA. Нейродегенеративный процесс изучали гистологическим исследованием. Результаты. После экспериментального инсульта установлена реактивация ВПГ І типа. Гистологическим исследованием подтверждено наличие нейродистрофического процесса вокруг очага кровоизлияния, в частности - в гиппокампе. Работа продемонстрировала диагностическую ценность молекулярно-биологических методов в выявлении герпесвирусной инфекции в биологических образцах (плазме крови, гомогенатах органов животных). Выводы. Экспериментальное исследование дало новые данные о патогенезе герпесвирусной инфекции после острого инсульта и ее роли в развитии осложнений. Дополнительно показана диагностическая ценность лабораторных методов определения ВПГ.

Кл ючев ы е сл ов а: герпес, инсульт, диагностика, патогенез.

Received 22.01.2016 